African Crop Science Journal by African Crop Science Society is licensed under a Creative Commons Attribution 3.0 Uganda License. Based on a work at www.ajol.info/ and www.bioline.org.br/cs DOI: http://dx.doi.org/10.4314/acsj.v24i2.1

\title{
EFFECT OF SORGHUM SEED TREATMENT IN BURKINA FASO VARIES WITH BASELINE CROP PERFORMANCE AND GEOGRAPHICAL LOCATION
}

\author{
P.E. ZIDA, B.J. NÉYA, W.R. SOALLA, S.M. JENSEN ${ }^{1}$, M.S. STOKHOLM ${ }^{1}$, M. ANDRESEN ${ }^{1}$, \\ M.H. KABIR ${ }^{1}$, P. SÉRÉMÉ and O.S. LUND ${ }^{1}$ \\ Institut de l'Environnement et de recherches Agricoles (IN.E.R.A.), 04, P. O. Box 8645, \\ Ouagadougou 04, Burkina Faso \\ ${ }^{1}$ Department of Plant and Environmental Science, University of Copenhagen, Højbakkegård Allé 13, 2630 \\ Taastrup, Denmark \\ Corresponding author: osl@plen.ku.dk
}

(Received 11 August, 2015; accepted 25 April, 2016)

\begin{abstract}
Sorghum [Sorghum bicolor (L.) Moench] is a major subsistence crop throughout the region of Sahel. With the exception of seeds and labour, no agricultural inputs are in general used in sorghum production since the grain is of a relatively low commercial value and the risk of losing the crop to drought, flooding, etc. is substantial. A meta-analysis of 118 field experiments was carried out to identify conditions in which two protective seed treatments could support a yield increase of sorghum in Burkina Faso. The two treatments were: i) treatment with the pesticide Calthio $\mathrm{C}$ (thiram and chlorpyrifos) and ii) treatment with an aqueous extract from the plant Eclipta alba. Both treatments were found to produce a yield increase (Medians: Calthio C $+199 \mathrm{~kg} \mathrm{ha}^{-1}$, $\mathrm{P}<2 \times 10^{-9} ;$ E. alba $\left.+90.5 \mathrm{~kg} \mathrm{ha}^{-1} \mathrm{P}<4 \times 10^{-4}\right)$. A strong relative effect of Calthio $\mathrm{C}$ on yield $(+36 \%)$ was found for field experiments with a low baseline yield. A strong relative effect of $E$. alba extract on yield $(+22 \%)$ was found for experiments with a low baseline of emergence. ANOVA of the 118 field tests showed that baseline crop performance (yield and emergence) and the effect of seed treatments were strongly linked to geographical location (twelve different villages included). Roots from sorghum in the village showing the strongest effect of both seed treatments ( $>40 \%$ yield increase) were found to carry a comparatively high load of the infectious ascomycetes: Fusarium equiseti, Macrophomina phaseolina and Curvularia lunata.
\end{abstract}

Key Words: Curvularia lunata, Fusarium equiseti, Macrophomina phaseolina, Sorghum bicolor

\section{RÉSUMÉ}

Le sorgho [Sorghum bicolor (L.) Moench] est une culture de subsistance de première importance dans toute la région du Sahel. Exception faite des semences et de la main-d'oeuvre, aucun intrant agricole n'est en général utilisé dans la production étant donné que le grain a une valeur commerciale relativement faible et le risque de perte de culture par la sècheresse, les inondations, etc. est élevé. Une macro-analyse portant sur 118 essais au champ a été effectuée pour déterminer les conditions selon lesquelles deux traitements de protection de semences pourraient soutenir une augmentation de rendement du sorgho au Burkina Faso. Les deux traitements ont été: 1) saupoudrage de semences avec le pesticide Calthio C (thirame et chlorpyrifos) et 2) trempage des semences dans un extrait aqueux de la plante Eclipta alba. Les deux traitements ont occasionné un accroissement du rendement (valeurs médianes: Calthio $\mathrm{C}+199 \mathrm{~kg} \mathrm{ha}^{-1}, \mathrm{P}<2 \times 10^{-9} ; E$. alba $\left.+90.5 \mathrm{~kg} \mathrm{ha}^{-1}, \mathrm{P}<4 \times 10^{-4}\right)$. Un effet relatif élevé du Calthio C sur le rendement $(+36 \%)$ a été noté pour les champs expérimentaux ayant un rendement initial faible. Un effet relatif élevé de l'extrait de $E$. alba sur le rendement $(+22 \%)$ a été noté pour les expérimentations ayant une émergence initiale faible. L'analyse de variance des 118 tests a montré que la performance de la culture (rendement 
et émergence) et l'effet du traitement des semences étaient fortement liés à la localisation géographique (12 villages différents impliqués). Les racines des plantes dans le village ayant montré le plus fort effet des deux traitements de semences (accroissement de rendement $>40 \%$ ) portaient une charge relativement élevée d'Ascomycètes infectieux : Fusarium equiseti, Macrophomina phaseolina et Curvularia lunata.

Mots Clés: Curvularia lunata, Fusarium equiseti, Macrophomina phaseolina, Sorghum bicolor

\section{INTRODUCTION}

Sorghum [Sorghum bicolor (L.) Moench] is a major subsistence crop throughout the region of Sahel. With the exception of seeds and labour, no agricultural inputs are in general used in sorghum production since the grain is of a relatively low commercial value and the risk of losing the crop to drought, flooding, etc. is substantial. Nonetheless, the use of seed treatment technology is of some interest since it is generally of low cost and relatively undemanding in terms of labour. However, relevant documentation of the effect of seed treatments on subsistence crops is often insufficient or does not adequately represent the real-life situation of the most common cropping systems in the region. Recently, we reported a $25 \%$ yield increase for sorghum treated with the binary pesticide, Calthio C (Zida et al., 2012). The study was conducted on multiple farms in Burkina Faso, during two consecutive growing seasons. The same study demonstrated a yield increase of $17 \%$ for seed treatment with an aqueous extract of the medicinal and locally abundant weed plant, Eclipta alba (L.) Hassk. However, a large variability in the effect was in general observed for both treatments, making it difficult to translate the results into reliable recommendations.

A pesticide Calthio $\mathrm{C}$ is produced locally in Burkina Faso as a dry powder for seed treatment. One of the two active compounds, thiram (tetramethylthiuram disulfide) belongs to the group of dithiocarbamates and acts as a broad spectrum fungicide, targeting the redox-balance of fungi by inactivation of glutathione reductase (Elskens and Penninckx, 1995). Thiram is classified as a contact fungicide and has been demonstrated to increase emergence and/or yield in sorghum by seed treatment (Hasan, 2001; Girish et al., 2004). The other active compound of Calthio $C$ is the organophosphate, Chlorpyrifos (IUPAC name $O, O$-diethyl $O-3,5,6$-trichloropyridin-2-yl phosphorothioate). The main biological target of this compound is the insect acetylcholinesterase (Barron and Woodburn, 1995). Thus, the binary pesticide meets the general recommendation by FAO to apply both a fungicide and an insecticide in the treatment of sorghum seeds (FAO, 2011).

The medicinal plant, Eclipta alba, review by Jahan et al. (2014) is common in Burkina Faso and an aqueous extract of the whole plant (root, stem and leaves) was first proposed for seed treatment of sorghum by Zida et al. (2008a). Later, the effect on yield was confirmed in a countrywide study. It was demonstrated that the positive effect of the plant extract was specific compared to soaking of seeds in pure water (Zida et al., 2012). The biological mechanism of action of $E$. alba extract is still unknown, but a dose dependent inhibition of the fungal pathogen, Epicoccum sorghinum (previously Phoma sorghina or Leptosphaeria sacchari, Aveskamp et al., 2010) was demonstrated by Zida et al. (2012). Epicoccum sorghinum is highly abundant on seeds of sorghum in Burkina Faso (Zida et al., 2008b). Also for Fusarium oxysporum and Fusarium subglutinans, a dose-dependent inhibition by an aqueous extract from leaves of E. alba has been reported (Saraswathy and Kumaran, 2012). The objective of this study was to analyze sources of variation in the effect of sorghum seed treatment observed in several independent field trials in Burkina Faso testing the pesticide, Calthio C, and the E. alba plant extract.

\section{MATERIALS AND METHODS}

Selection of field tests. Data for the meta-analysis was extracted from a total of eight field trials of sorghum carried out by the Institut de l'Environnement et de Recherches Agricoles (INERA, Burkina Faso) from 2009 to 2013, for three treatments, namely (i) non-treated seeds, (ii) seeds treated with Calthio $\mathrm{C}$, and (iii) seeds treated with 
E. alba extract at high dose. Only field experiments for which both emergence and yield has been registered were included. A total of 118 field experiments were in this way included for analysis, including 53 field experiments from three trials described by Zida et al. (2012). Field experiments were carried out at 12 villages located in Central Burkina Faso (Kindi, Kamboinsé, Zorgho, Ipendo, Diapangou, Dapelgo, Kouria, Ouanda); and in Northern Burkina Faso (Pobé, You, Bani, Dori). Except for experiments at Kamboinsé Research Station, all experiments were carried out in fields of farmers. A subset of the 118 experiments was carried out from 20102013 , testing identical seed samples in two villages, Kindi and Diapangou. This subset consisting of eleven paired experiments was extracted separately from the data set in order to compare results directly between these two villages.

Pesticide and botanical extract. The binary pesticide, Calthio $\mathrm{C}$, containing both the fungicide, thiram $(25 \%)$, and the insecticide, chlorpyrifos-ethyl (25\%) was obtained as a dry powder from the company Saphyto (BoboDioulasso in Burkina Faso).

Whole plants of E. alba (L.) Hassk. were collected by uprooting (pulling by hand) of wild plants growing in fields and humid sites near Ouagadougou, Burkina Faso. Soil particles on roots were removed by rinsing in tap water. The collected plant material was air-dried, ground into powder and sieved with a mesh of $2 \mathrm{~mm}$ diameter. The plant powder was stored in sealed plastic bags, in darkness, at room temperature for up to 1 year. An aqueous botanical extract was obtained from the plant powder by mixing it with distilled water at concentrations of 10 or $12.5 \% \mathrm{w} / \mathrm{v}$. This was followed by incubation for passive extraction at $25-30^{\circ} \mathrm{C}$ for 20 hours. The aqueous extract was filtered through a cheesecloth to remove larger particles.

Seed sampling and treatment. A total of 12 independent seed samples were used in the study: 11 were purchased from farmers from seven different villages in Burkina Faso (Kouria, Ipendo, You, Zorgho, Dapelgo, Kindi, Diapangou); and one seed sample (Kapelga) produced by INERA near Ouagadougou. Seeds were in all cases used for the subsequent growing season (storage $<9$ months). All seed treatments were performed by INERA at Kamboinse Research Station, Ouagadougou. Calthio C was applied as a dry powder at $4 \mathrm{~g} \mathrm{~kg}^{-1}$ of seeds, up to one day before sowing. Seed treatment with $E$. alba extract was conducted as "high dose" treatment, but with some variations between different trials: concentration of plant extract applied was either $10 \%$ (66 experiments) or 12.5\% (52 experiments). Soaking time was either 10 hours (82 experiments) or 20 hours (36 experiments). After soaking in plant extracts, seeds were dried for one day at room temperature before sowing. In the meta-analysis, all treatments with E. alba extract were considered as one category (same treatment).

Field experiments. Seeds were sown in rows with distances of $80 \mathrm{~cm}$ between rows and $40 \mathrm{~cm}$ between hills in the same row. Four to six seeds were sown per hill, and 15 days after sowing, the number of emerged seedlings per hole was reduced to a maximum of 4 seedlings. In all fields, mineral fertiliser consisting of nitrogenphosphorus-potassium (NPK 14-23-14) was applied at $100 \mathrm{~kg} \mathrm{ha}^{-1}$ at sowing. Urea $\left(50 \mathrm{~kg} \mathrm{ha}^{-1}\right)$ was applied 30 days post-emergence. In terms of dimensions, two types of field experiments were included either small plots ( 95 field tests, three plots per treatment in a randomized complete block design of plots with 5 rows, $5 \mathrm{~m}$ long) or large plots (23 field tests, a single plot per treatment with 20 rows, $6 \mathrm{~m}$ long). In all experiments the three seed treatments (No treatment, Calthio C and $E$. alba extract) were tested in parallel. After 3-4 weeks, crop emergence was determined visually by counting the percentage of seed holes populated with emerging plants in each plot. At harvest, grains were collected from central rows of each plot (3 or 18 rows, dependent on plot size) and yield was determined after 2 weeks of sun drying of the harvested grain.

Statistical analysis. Field averaged data on total and relative yield and total and relative emergence were presented as mean and medians for each treatment. Treatment differences and effects of baseline field level of yield and emergence were 
tested in mixed linear models, including experiment, village and year as random effects. Total yield, relative yield and relative emergence were $\log$ transformed before analysis. Percentage of variance explained by different factors were found using an ANOVA with absolute values, relative, normalised $\left(\%^{\mathrm{N}}\right)$ values and treatment effects as dependent variables.

All analyses were performed using the open source statistical programming environment $\mathrm{R}$ version 3.2.2 ( $\mathrm{R}$ Core Team 2015). Yield data from 11 paired experiments from Kindi and Diapangou were compared using Paleontological Statistics software package for education and data analysis (PAST), Version 2.1 (Hammer et al., 2001) for calculating intervals of $95 \%$ confidence of means (t-test) and $\mathrm{P}$ values of differences between medians of groups (Wilcoxon paired sample analysis).

Root-associated mycoflora DNA analysis. In order to compare fungal infection of sorghum between different locations, roots of mature plants were analysed by DNA amplicon sequencing, testing both the level of infection (18S amplicon ; ratio of Fungal DNA to Plant DNA) and the relative distribution of fungal species (ITS2 amplicon).

Non-treated seeds of two seed samples, Kouria and Kapelga, were sown in two separate fields near the village Diapangou and at two separate fields near the village, Kindi. At crop maturity, DNA from roots was extracted and pooled from nine representative plants for each seed sample in each village. Roots were grinded in liquid nitrogen and DNA was extracted using the DNAeasy Qiagen Plant minikit (Qiagen Group, CA, USA). This was followed by spectrophotometric determination of the DNA concentration (260 $\mathrm{nm}$ absorbance) and purity (260/280 nm ratio) on a NanoDrop 2000, (NanoDrop Technologies Inc., Wilmington, Delaware, USA). The purified DNA from the four samples was used as a template for PCR amplification of two different ribosomal target sites: $18 S$ rDNA and ITS2; followed by 454pyrosequencing.

$18 S$ rDNA Primers were developed for amplification of the ribosomal small subunit ( $18 S$ rDNA) from the community of fungi, oomycetes and nematodes, including selectivity against plant DNA (Table 1). ITS2 primers specifically targeting the ribosomal internal transcribed spacer 2 of ascomycetes, were modified after Louarn et al. (2013) (Table 1). In addition to specific target-binding sequences, all primers were fused to a sequencing adaptor as specified by the sequencing company (Eurofins, Germany).

Forward primers contained a multiplex identifier (MID) tag for sample barcoding. A 14 bp separator sequence was inserted in the reverse primers, separating the sequencing adaptor from the specific primer part (Table 1). Each PCR amplification was conducted in a volume of $41 \mu \mathrm{l}$ using $10 \mathrm{ng}$ template DNA, 2.5\% DMSO, $1.5 \mathrm{mM}$ $\mathrm{MgCl}_{2}, 0.2 \mathrm{mM}$ dNTP, $1 \mathrm{x}$ colourless GoTaq Reaction buffer and $0.024 \mathrm{U}$ GoTaq DNA Polymerase (Promega Corporation, WI, USA). For the $18 S$ amplicon: $1.0 \mu \mathrm{M}$ forward and $1.0 \mu \mathrm{M}$ of each of the four reverse primers was added to each reaction. For the ITS 2 amplicon, $1.95 \mu \mathrm{M}$ forward and $0.98 \mu \mathrm{M}$ of each of the two reverse primers was added. PCR was conducted in a MJ mini ${ }^{\mathrm{TM}}$ Personal Thermal Cycler (Bio-Rad Laboratories Inc.). The $18 S$ PCR programme was performed in 2-phases, as follows: 3 min initial DNA denaturation at $95^{\circ} \mathrm{C}$, followed by phase- 1 with 10 cycles of $20 \mathrm{~s}$ at $94^{\circ} \mathrm{C}, 15 \mathrm{~s}$ primer annealing at $50{ }^{\circ} \mathrm{C}, 30 \mathrm{~s}$ extension at $72{ }^{\circ} \mathrm{C}$ and phase- 2 with 25 cycles of $20 \mathrm{~s}$ at $94^{\circ} \mathrm{C}, 20 \mathrm{~s}$ primer annealing at $65^{\circ} \mathrm{C}, 30 \mathrm{~s}$ extension at $72{ }^{\circ} \mathrm{C}$, and a $7 \mathrm{~min}$ final extension step at $72{ }^{\circ} \mathrm{C}$, yielding a product size of $\sim 460 \mathrm{bp}$. The ITS2 PCR programme: 3 min at 95 ${ }^{\circ} \mathrm{C}$, followed 32 cycles of $20 \mathrm{~s}$ at $94{ }^{\circ} \mathrm{C}, 15 \mathrm{~s}$ at 56 ${ }^{\circ} \mathrm{C}, 20 \mathrm{~s}$ at $72{ }^{\circ} \mathrm{C}$ and a $5 \mathrm{~min}$ final extension at 72 ${ }^{\circ} \mathrm{C}$, yielding a product size of $\sim 250 \mathrm{bp}$. PCR products were subjected to gel electrophoresis in $1.5 \%$ agarose gels, including $0.25 \mu \mathrm{l}(0.07 \%)$ ethidium bromide/ml of $0.5 \mathrm{x}$ TBE buffer $(40 \mathrm{mM}$ Tris-Cl, pH 8.3, 45 mM boric acid, 1 mM EDTA). Subsequently, amplicons were excised from gels and purified using MinElute Gel Extraction Kit (Qiagen Group, CA, USA). The concentration of purified rDNA was determined using the NanoDrop 2000, as described above.

\section{Pyrosequencing and DNA cluster analysis.} Equimolar concentrations of the two amplicons, 18S and ITS2, were mixed and 454-pyrosequenced at the Roche GS FLX Titanium platform, followed 
by initial sorting of sequence data at Eurofins, according to sample specific MID tags. The pyrosequencing data sets were processed through a series of sequence trimming and quality control steps, to extract high quality regions, followed by single linkage clustering into operational taxonomic units (OTUs), with a 98.5\% similarity cut-off for clustering of the $18 \mathrm{~S}$ amplicon reads and a 99\% cut-off for clustering of the ITS2 reads, using the open source SCATA pipeline (Sequence Clustering and Analysis of Tagged Amplicons (http://scata.mykopat.slu.se); Durling et al., 2011). Representative sequences from the 10 most abundant OTUs were taxonomically annotated to the finest possible taxonomic level, by comparison with GenBank accessions from type culture isolates, if available. The level of root infection was expressed as the number of 18S DNA reads from four cathegories of nonplant eukaryotes (Ascomycetes, Basidiomycetes, Nematodes, Other) per 100 reads of Plant $18 \mathrm{~S}$ rDNA. The distribution of different species of ascomycetes was calculated directly from the distribution of ITS2 $\mathrm{rDNA}$ reads.

\section{RESULTS}

Overall effect of seed treatments. Overall, metrics (means and medians) of the meta-data set are given in Table 2. Compared to the control (NT), a significant increase in both emergence and yield was obtained for the two treatments. The strongest effect of seed treatment on yield (absolute values, Table 2A) was found for Calthio $\mathrm{C}$ (median increase: $+199 \mathrm{~kg} \mathrm{ha}^{-1} \sim+21.5 \%$; $\mathrm{p}<2 \mathrm{x}$ $\left.10^{-9}\right)$; whereas the E. alba extract showed a more moderate effect $\left(+90.5 \mathrm{~kg} \mathrm{ha}^{-1} \sim+12.9 \% ; \mathrm{P}<4 \mathrm{x}\right.$ $10^{-4}$ ). A similar pattern was observed with respect to emergence, for which the observed median increases (absolute values) were minor (5-9\%), but strongly significant.

Baseline crop performance and the effect of treatment. From Table 2A, a skew distribution of absolute yield is evident, i.e., aboslute yield increases calculated from the total means were somewhat different from yield increases measured by medians, particularly with respect to Calthio C ( $14.9 \%$ vs $21.5 \%$, respectively). Since this discrepancy could be caused by systematic 
TABLE 2. Overall effects of seed treatments

\begin{tabular}{|c|c|c|c|c|c|c|}
\hline \multirow[t]{2}{*}{118 field tests } & \multicolumn{3}{|c|}{ Emergence } & \multicolumn{3}{|c|}{ Yield } \\
\hline & NT & Cal & E.a. & NT & Cal & E.a. \\
\hline A) Absolute values & & $\%$ & & & $\mathrm{Kg} \mathrm{ha}^{-1}$ & \\
\hline Mean & 77.6 & 86 & 82.3 & 1087 & 1250 & 1197 \\
\hline Increase of mean & - & 8.4 & 4.7 & - & 163 & 111 \\
\hline$\%$ increase of mean & - & $10.80 \%$ & $6.10 \%$ & - & $14.90 \%$ & $10.20 \%$ \\
\hline Median & 78.6 & 88.9 & 85 & 820 & 1049 & 965 \\
\hline Median increase & - & 7.2 & 3.9 & - & 199 & 90.5 \\
\hline Median \% increase & - & $9.20 \%$ & $5.40 \%$ & - & $21.50 \%$ & $12.90 \%$ \\
\hline$P$ value (medians ; simiarity to NT) & & $2 \times 10^{-16}$ & $5 \times 10^{-7}$ & & $2 \times 10^{-9}$ & $4 \times 10^{-4}$ \\
\hline B) Relative and normalised values* & & $\%^{N}$ & & & $\%^{N}$ & \\
\hline Mean (Mean_NT $=100 \%^{N}$ ) & 100 & 111.5 & 106.6 & 100 & 122 & 112 \\
\hline$\%$ increase of mean & - & $11.50 \%$ & $6.60 \%$ & - & $22 \%$ & $12 \%$ \\
\hline$P$ value (means ; similarity to NT) & & $2 \times 10^{-16}$ & $2 \times 10^{-9}$ & & $3 \times 10^{-13}$ & $2 \times 10^{-5}$ \\
\hline
\end{tabular}

${ }^{*}$ Field averaged values normalized to $\mathrm{NT}=100 \%{ }^{\mathrm{N}}$. NT $=$ No treatment, Cal $=$ Calthio C, E. $a=$ Eclipta alba extract

differences between high-yielding and lowyielding fields, we performed an overall analysis of data comparing the effect of seed treatments with respect to the baseline level of crop performance (yield and emergence). The term "baseline" was here used operationally to describe the mean of all treatments within an individual field test (Emerg_All and Yield_All, respectively). For this analysis, the 118 field experiments were stratified in two ways: (i) according to Yield_All being higher or lower than the median Yield_All value $\left(972 \mathrm{~kg} \mathrm{ha}^{-1}\right.$; Table 3 A,B), and (ii) according to the value of Emerg_All being higher or lower than the median Emerg_All value $(83.6 \%$, Table $3 \mathrm{C}, \mathrm{D})$. By these stratifications, it was found that treatments with Calthio $\mathrm{C}$ caused the strongest positive effect on yield $(+36 \%)$ in field experiments with a low baseline yield $(\mathrm{P}=0.001)$. For treatment with $E$. alba extract, the strongest effect on yield $(+22 \%)$ was found in field experiments with a low baseline emergence $(\mathrm{P}=0.0093)$.

The same analysis was performed with respect to the interaction between crop performance and seed treatment using emergence as the response parameter (Table 4). For both treatments, Cal and E.a., it was found that the effect on emergence was stronger on fields with a low baseline level of emergence (Table 4 C, D).

Sources of variance. The meta-dataset was subjected to overall analysis of variance (ANOVA) in order to compare the effects of crop performance found above to other factors potentially influencing crop yield and emergence. The influence of "Year" and location ("Village") were compared with the "Treatment" for both absolute and relative values (Table 5A and 5B, respectively). From this analysis "Village" was the most important factor (19-33\%) influencing absolute values of both yield and the level of emergence; whereas "Year" and "Treatment" were only minor factors (2-7\%, Table 5A). In contrast, for relative and normalised values "Treatment" turned out as the most important individual factor (13-24\%, Table 5B), confirming a statistically significant effect thereof. However, for both absolute and relative values the main part of the variation (64-86\%) was still unaccounted for (residual) by these analyses. To elucidate patterns of variation on specific treatments (Calthio $\mathrm{C}$ and E. alba extract, 
TABLE 3. Interaction between crop performance and seed treatment on yield

\begin{tabular}{|c|c|c|c|c|c|c|c|}
\hline \multirow[t]{2}{*}{ 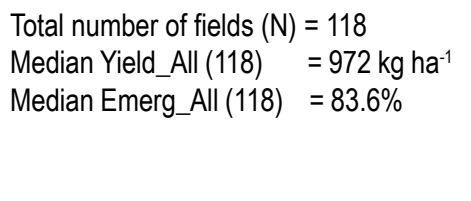 } & \multirow[t]{2}{*}{$\mathrm{N}$} & \multicolumn{3}{|c|}{$\begin{array}{l}\text { Yield (median) } \\
\text { absolute values } \\
\quad\left(\mathrm{kg} \mathrm{ha}^{-1}\right)\end{array}$} & \multicolumn{3}{|c|}{$\begin{array}{l}\text { Yield (median) Rel. } \\
\text { and Norm. values } \\
\qquad(\% \mathrm{~N})\end{array}$} \\
\hline & & NT & Cal & E.a. & NT & Cal & E.a. \\
\hline \multicolumn{8}{|l|}{ Stratification by Yield_All } \\
\hline A) Fields with Yield_All $<972 \mathrm{~kg} \mathrm{ha}^{-1}$ & 59 & 478 & 649 & 561 & 100 & 136 & 117 \\
\hline B) Fields with Yield_All >972 $\mathrm{kg} \mathrm{ha}^{-1}$ & 59 & 1456 & 1640 & 1595 & 100 & 113 & 109 \\
\hline$P$ value $(A=B)$ & - & - & - & - & - & 0.001 & 0.228 \\
\hline \multicolumn{8}{|l|}{ Stratification by Emerg_All } \\
\hline C) Fields with Emerg_All <83.6\% & 59 & 841 & 1093 & 1127 & 100 & 130 & 122 \\
\hline D) Fields with Emerg_All >83.6\% & 59 & 1138 & 1341 & 1197 & 100 & 118 & 105 \\
\hline$P$ value $(C=D)$ & - & - & - & - & - & 0.088 & 0.0093 \\
\hline
\end{tabular}

$\mathrm{N}=$ Number of field experiments, $\mathrm{NT}=$ No treatment, $\mathrm{Cal}=$ Calthio $\mathrm{C}, \mathrm{E} . \mathrm{a}=$ Eclipta alba extract

TABLE 4. Interaction between crop performance and seed treatment on emergence

\begin{tabular}{|c|c|c|c|c|c|c|c|}
\hline \multirow[t]{2}{*}{$\begin{array}{l}\text { Total number of fields }(\mathrm{N})=118 \\
\text { Median Yield_All }(118)=972 \mathrm{~kg} \mathrm{ha}^{-1} \\
\text { Median Emerg_All }(118)=83.6 \%\end{array}$} & \multirow[t]{2}{*}{$\mathrm{N}$} & \multicolumn{3}{|c|}{$\begin{array}{l}\text { Emergence } \\
\text { absolute values } \\
\qquad(\%)\end{array}$} & \multicolumn{3}{|c|}{$\begin{array}{c}\text { Emergence } \\
\text { Rel. and Norm. values } \\
\qquad(\% \mathrm{~N})\end{array}$} \\
\hline & & NT & Cal & E.a. & NT & Cal & E.a. \\
\hline \multicolumn{8}{|l|}{ Stratification by Yield_All } \\
\hline A: Fields with Yield_All <972 kg ha-1 & 59 & 73.7 & 83 & 80.3 & 100 & 113 & 109 \\
\hline B: Fields with Yield_All >972 kg ha-1 & 59 & 77.8 & 85.3 & 80.6 & 100 & 110 & 104 \\
\hline$P$ value $(A=B)$ & - & - & - & - & - & 0.172 & 0.011 \\
\hline \multicolumn{8}{|l|}{ Stratification by Emerg_All } \\
\hline C: Fields with Emerg_All $<83.6 \%$ & 59 & 68.9 & 78.3 & 74.7 & 100 & 114 & 109 \\
\hline D: Fields with Emerg_All >83.6\% & 59 & 85.5 & 92.9 & 89 & 100 & 109 & 104 \\
\hline$P$ value $(C=D)$ & - & - & - & - & - & 0.017 & 0.044 \\
\hline
\end{tabular}

$\mathrm{N}=$ Number of field experiments, $\mathrm{NT}=$ No Treatment, $\mathrm{Cal}=$ Calthio $\mathrm{C}, E . a=$ Eclipta alba extract

respectively), ANOVA was performed on relative values for each of these treatments, while incorporating also the categories of crop performance found to influence the effect of both treatments above (Table 6). By this comparison, it became evident that "Village" was by far the most dominant individual factor influencing particularly the relative effect on yield (15-24\%).
However, the major part of the variation was still the residual, indicating a large experimental variability in the system. The finding of "Village" being a major determinant of the relative effect of seed treatments is illustrated in Figure 1. It is important to note that application of the pesticide in all villages caused a mean positive effect, whereas application of the plant extract in 4 cases 
TABLE 5A. Sources of variance of crop performance (absolute values)

\begin{tabular}{lllcc}
\hline 118 field tests & Year $^{*}$ & Village $^{\star *}$ & Treatment $^{\star \star *}$ & Residual \\
\hline Emergence $(\%)$ & 7.1 & 19.2 & 7.7 & 66.0 \\
Yield $\left(\mathrm{kg} \mathrm{ha}^{-1}\right)$ & 1.6 & 32.6 & 1.6 & 64.2 \\
\hline
\end{tabular}

*Years 2009-2013; **12 villages; *** Three treatments (NT, Cal, E.a.)

TABLE 5B. Sources of variance of crop performance (relative and norm. values)

\begin{tabular}{lllll}
\hline 118 field tests & Year $^{*}$ & Village $^{* *}$ & Treatment $^{* * *}$ & Residual \\
\hline Emergence $(\% \mathrm{~N})$ & 0.0 & 0.0 & 24.3 & 75.7 \\
Yield $(\% \mathrm{~N})$ & 0.0 & 0.3 & 13.4 & 86.3 \\
\hline
\end{tabular}

*Years 2009-2013; **12 villages; ${ }^{* * *}$ Three treatments (NT, Cal, E.a.)

TABLE 6. Sources of variance for specific treatments - relative and norm. values

\begin{tabular}{lcccccc}
\hline 118 field tests & Treatment & Year & Village & $\begin{array}{c}\text { Emergence_All } \\
\text { High/Low }\end{array}$ & $\begin{array}{c}\text { Yield_All } \\
\text { High/Low }\end{array}$ & Residual \\
\hline Emergence $\left(\%{ }^{\mathrm{N}}\right)$ & Cal & 2.74 & 7.95 & 3.04 & 0.91 & 85.36 \\
& E.a. & 1.60 & 8.25 & 1.95 & 2.87 & 85.33 \\
Yield $(\% \mathrm{~N})$ & Cal & 3.97 & 15.21 & 1.45 & 5.02 & 74.35 \\
& E.a. & 3.07 & 24.45 & 3.85 & 0.65 & 67.98 \\
\hline
\end{tabular}

resulted in either no or a negative mean effect (Bani, Kindi, You, Zorgho).

\section{Data extracted for direct comparison of results}

in two villages. From Figure 1, it is clear that in Kindi village, either a slightly negative effect ($2.5 \%^{\mathrm{N}}$, E.a. $)$ or a very weak effect $\left(+7 \%^{\mathrm{N}}, \mathrm{Cal}\right)$ was observed in the 22 experiments included in the meta-data. In contrast, a more than $40 \% \mathrm{~N}$ yield increase was observed for both treatments as a mean of 24 experiments conducted near the village, Diapangou. In order to eliminate differences originating from different seed samples tested, minor variations in the protocol of seed treatment or any asymmetries with respect to "Year" of testing, eleven paired experiments were extracted from the meta-dataset in which field tests were conducted in the two villages simultaneously (same year), using the same seed samples and the same protocols, respectively (Fig. 2). This direct comparison confirmed the overall differences observed between the two villages described above. In addition, results from paired experiments were in agreement with the overall findings regarding a stronger effect of seed treatments being associated with a low baseline level of yield and emergence, respectively. The differences in relative yield increases observed between the two villages in paired experiments were significant for both Calthio $\mathrm{C}(\mathrm{P}<0.004)$ and E. alba extract $(\mathrm{P}<0.007)$.

Root associated mycoflora. During the last year of field testing, root-associated mycoflora of sorghum plants grown from non-treated seeds were compared between the two villages, Kindi and Diapangou. For each village, plants from two different seed samples (Kouria and Kapelga) were compared. The $18 \mathrm{~S}$ profile of the microflora (Fig. $3 \mathrm{~A}$ and $3 \mathrm{~B}$ ) revealed that ascomycetes were the 


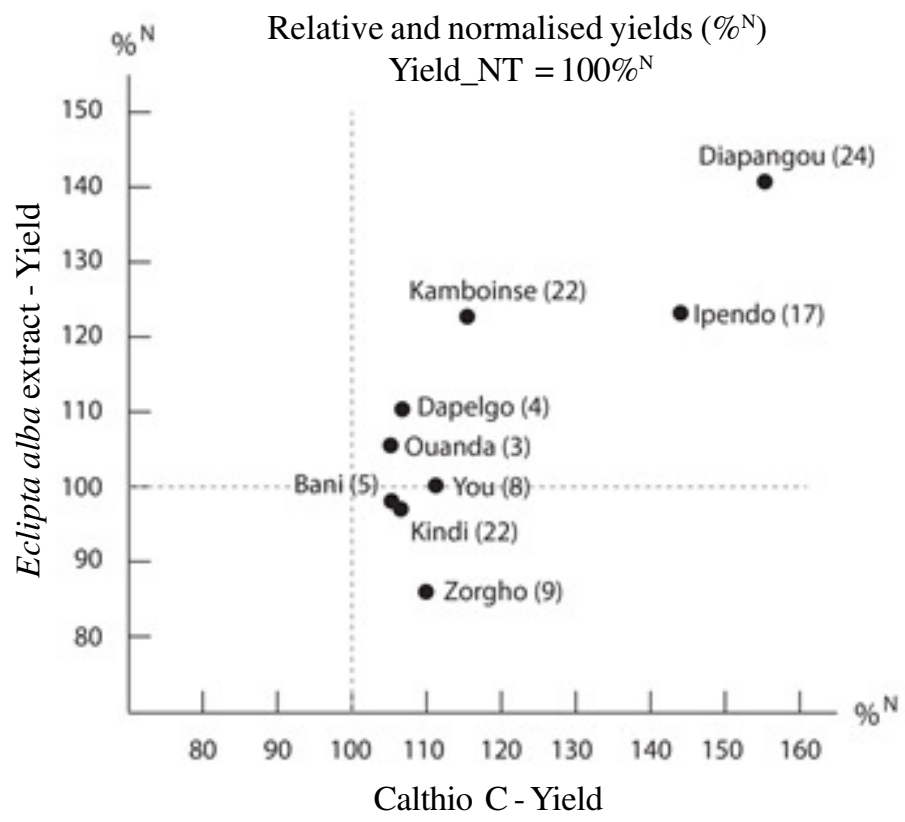

Figure 1. Effect of seed treatments on yield in nine different villages. From the meta-dataset, the mean relative and normalised yields $(\% \mathrm{~N})$ from nine different villages were extracted and plotted for the two seed treatments: Calthio $C$ and $E$. alba extract, respectively. Each of the nine villages was represented in the meta-data set by at least three independent field experiments (Actual number of experiments indicated in brackets). The data extracted covers 114 out of a total of 118 field tests. NT $=$ No treatment.

most dominating group of eukaryotic microbes in all samples. In addition, roots from plants grown at Diapangou had approximately a 3 -folds higher level of colonisation/infestation by ascomycetes compared to roots from Kindi. The distribution of ascomycetes at genus and species levels was subsequently assessed using ITS2 rDNA amplicon sequencing (Table 7). In plants grown near Diapangou, approximately $42.2 \%$ of ascomycetous rDNA originated from the genus Fusarium, whereas this genus only constituted $16.6 \%$ in plants from Kindi (mean values). The species, Fusarium equiseti, was by far the most dominating species of Fusarium at both locations. Also, though less abundantly, the species of Macrophomina phaseolina and Curvularia lunata were detected at higher levels in roots from Diapangou compared to Kindi (Table 7). At Kindi, a dominating group of fungi included several species of unknown sordariomycetes (28.2\% of ascomycetous rDNA). A representative sequence for each Operational Taxonomic Unit (OTU) was taxonomically annotated by comparison to reference accessions in GenBank (Table 8).

\section{DISCUSSION}

Geographical location of the trial site ("Village") was the strongest individual factor influencing the effect of seed treatments. Minor interaction was found with the baseline level of crop performance (emergence and yield) for each experiment. Roots from mature sorghum plants were found to have a relatively high level of fungal infection in the village, Diapangou, where seed treatments had shown the strongest response ( $>40 \%$ yield increase for any of the two treatments, $\mathrm{N}=24)$. The findings are discussed in detail below. Aspects relevant to farmer's choice of technology are discussed in the section: perspectives.

Overall effect of seed treatments. The overall positive effects on emergence and yield found for both treatments, and the high number of field 


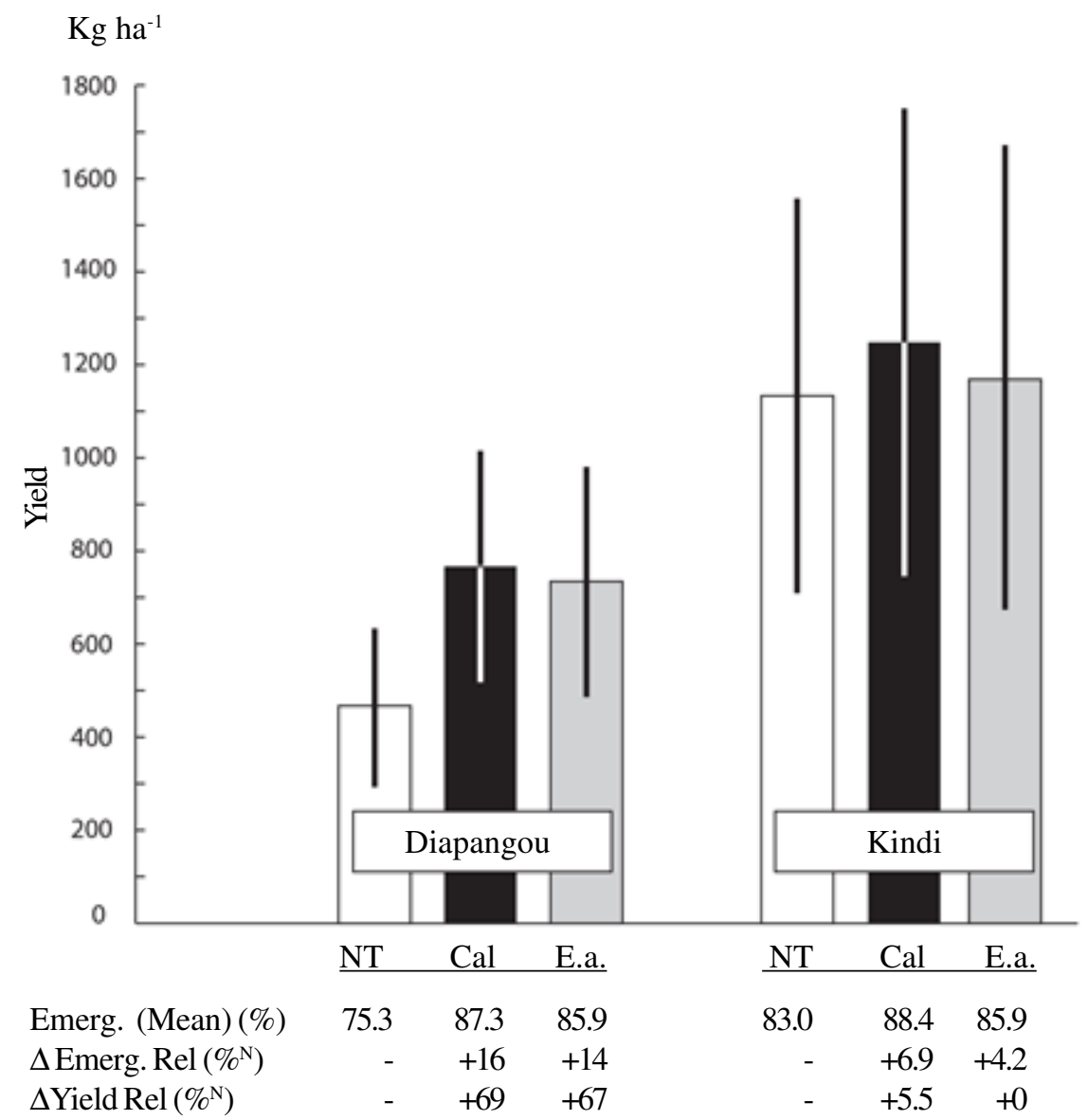

Figure 2. Identical seed samples tested in two villages ( $2 \times 11$ field tests). From the meta-data set eleven paired experiments were extracted in which the same seed sample was tested simultaneously in both Kindi and Diapangou. A total of four different growing seasons (2010-2013) were represented. Large bars represent the mean yield and small bars represent intervals of $95 \%$ confidence. Data for emergence and relative yield increase are tabulated below the $X$-axis of the graph.

experiments (118) for the first time allowed statistical significance to be obtained for absolute values of yield increases for both the pesticide (median: $+199 \mathrm{~kg} \mathrm{ha}^{-1} ;+21.5 \% ; \mathrm{P}<2 \times 10^{-9}$ ) and for the plant extract $\left(+90.5 \mathrm{~kg} \mathrm{ha}^{-1} ;+12.9 \% ; \mathrm{P}<4 \mathrm{x}\right.$ $\left.10^{-4}\right)$. When calculated as relative and normalised values (Table 2B), the mean effect of seed treatments were very similar to the median values described above, indicating that the metric conclusions were robust. The estimated increases found for emergence were in general associated with less uncertainty compared with the corresponding estimates found for increases in yield. This was not surprising since yield was measured at the end of the growing season and, therefore, was susceptible to variations accumulating over a much longer period, compared to emergence. However, the increases found for yield were markedly larger compared with those of emergence (approx. 2-fold for medians and relative, normalised values, Table 2). Two recent studies testing seed priming in maize and a number of other monocot crop plants have found a similar ratio $(2: 1)$ between yield and emergence (Sudozai et al., 2013, Soltani and Soltani, 2015). Factors such as crop establishment, crop uniformity or plant health, all positively influencing crop productivity and 
TABLE 7. Ascomycetes in roots of sorghum from two seed samples in two villages

\begin{tabular}{|c|c|c|c|c|c|c|c|c|}
\hline \multirow[b]{3}{*}{ Village (DIA, KIN) } & & \multicolumn{4}{|c|}{ DNA reads $(\%)$} & \multicolumn{2}{|c|}{ Mean $(\%)$} & \multirow[t]{3}{*}{ Dominant species (DIA (\%) - KIN (\%)) } \\
\hline & & \multicolumn{2}{|c|}{ Kouria seeds } & \multicolumn{2}{|c|}{ Kapelga seeds } & \multirow[b]{2}{*}{ DIA } & \multirow[b]{2}{*}{ KIN } & \\
\hline & & DIA & KIN & DIA & KIN & & & \\
\hline Ascomycetes, Class & Genus & & & & & & & \\
\hline \multirow{2}{*}{ Sordariomycetes } & Fusarium & 31.7 & 11.1 & 52.6 & 22.0 & $42.2^{*}$ & 16.6 & Fusarium equiseti (33 - 13\%) \\
\hline & Other & 3.1 & 21.9 & 9.5 & 34.6 & 6.3 & $28.2^{* *}$ & Uncultured Sordariales (2 - 8\%) \\
\hline \multirow[t]{4}{*}{ Dothideomycetes } & Epicoccum & 8.8 & 13.7 & 8.7 & 6.8 & 8.8 & 10.3 & Epicoccum sorghinum (9-10\%) \\
\hline & Cochliobolus & 4.3 & 1.4 & 10.3 & 3.4 & $7.3^{*}$ & 2.4 & Curvularia lunata $(3-1 \%)$ \\
\hline & Macrophomina & 15.0 & 0.3 & 2.3 & 0.7 & $8.7^{\star}$ & 0.5 & Macrophomina phaseolina (9-0.5\%) \\
\hline & Other & 7.4 & 6.8 & 1.8 & 13.5 & 4.6 & 10.1 & Cladosporium sp. (5 - 10\%) \\
\hline Eurotiomycetes & & 23.9 & 38.0 & 7.7 & 6.8 & 15.8 & 22.4 & Talaromyces/Penicillium sp (10 - 20\%) \\
\hline Other & & 5.9 & 6.7 & 7.1 & 12.2 & 6.5 & 9.5 & \\
\hline Total & & 100 & 100 & 100 & 100 & 100 & 100 & \\
\hline
\end{tabular}

DIA = Diapangou $; \mathrm{KIN}=$ Kindi. * More than two fold overrepresentation at Diapangou in plants from both seed samples; ${ }^{* *}$ More than two fold overrepresentation at Kindi in plants from both seed samples 

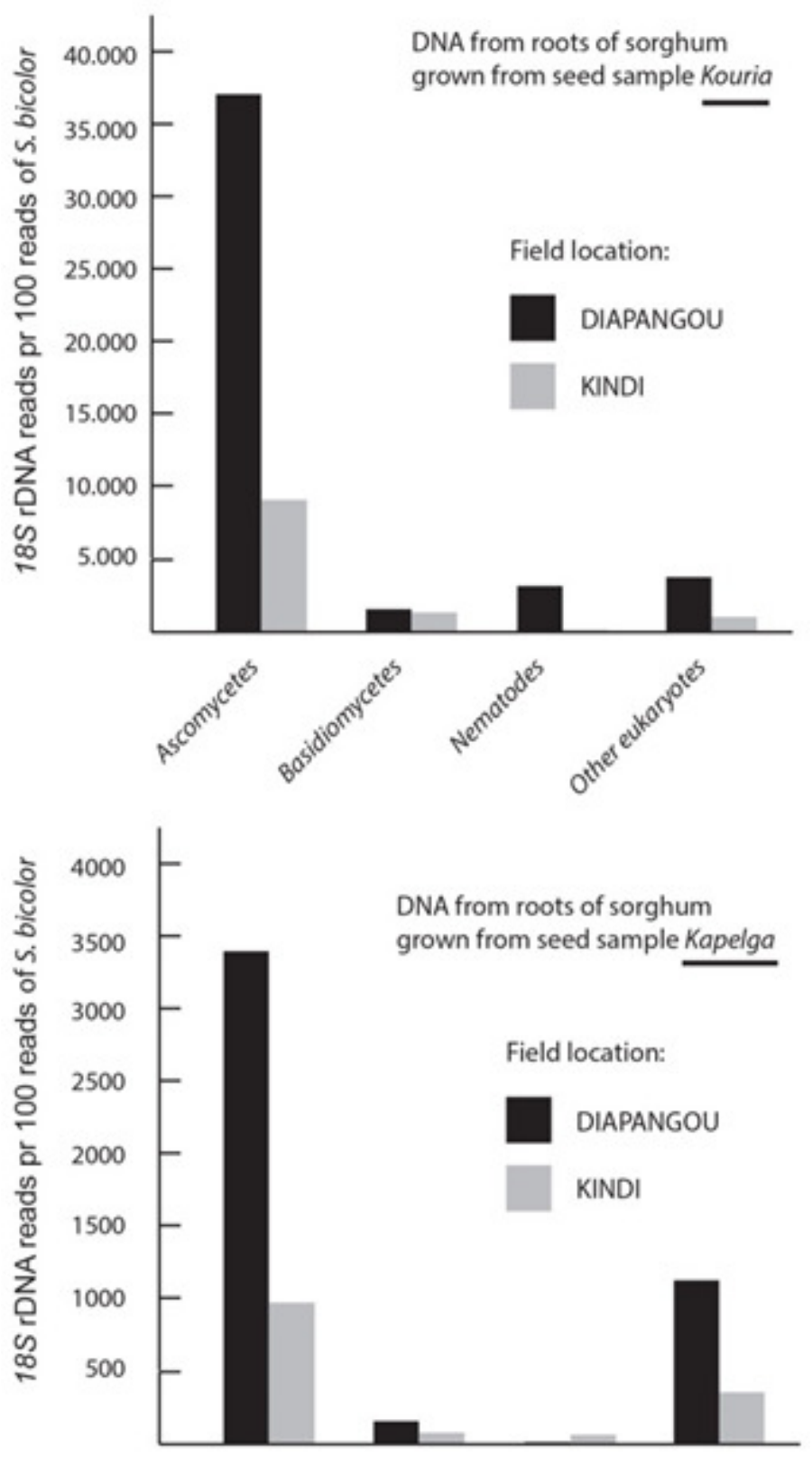

Figure 3. Root associated, eukaryotic microflora in sorghum from two villages and two seed samples. (A) Plants grown from seed sample Kouria; (B) Plants grown from seed sample Kapelga. Non-treated seeds of both seed samples were sown at the two villages, Diapangou and Kindi. $18 \mathrm{~S}$ rDNA from roots of mature plants were amplified and analysed as described. 
all linked to early plant growth, may explain the relatively large effect of seed treatment observed on yield compared to emergence.

Factors influencing the effect of seed treatment. A stronger response in yield was found for both seed treatments on fields having a low baseline crop performance (emergence and yield). We have not found other studies of seed treatments clearly addressing this point, but a similar inverse correlation (low baseline yield : high yield response to treatment) as here found for Calthio $\mathrm{C}$ has been reported also for fungicides applied as foliar sprays in maize (Paul et al., 2011). The same study found, that fields having a low baseline yield also had a relatively high disease index and thereby - theoretically - a larger potential to respond to antifungal treatments. A similar mechanism could potentially explain the observations made in the present study. We did not measure a disease index, but baseline crop emergence was found to be low in fields responding strongly to both treatments. A low rate of emergence could indicate the presence of seedling pathogens and a relatively high level of fungal infection was found in roots of plants growing in a village showing the strongest response to seed treatment compared to a village with very low response (see detailed discussion on mycoflora below). Overall, geographical location loosely defined as "village" was in the present study found to be by far the strongest factor influencing the effect of seed treatment (Table 6).

In addition, both the ANOVA of all 118 field experiments and the direct comparison of experiments at two selected villages showed that all three factors discussed above: baseline yield, baseline emergence and crop responsiveness to seed treatment interacted and even aggregated with geographical location (Table 5A and Fig. 2, respectively). A simple hypothesis uniting these findings could be that the seed treatments directly or indirectly provide protection against pathogens propagating to high levels in fields showing low baseline yield, low baseline emergence and a strong effect of seed treatments. From the literature of other crops (soybean, sweet corn) a few reports exist of an interaction between trial location and the effect of antifungal seed 
treatment on yield (Bradley, 2008; Schulz and Thelen, 2008; Wohleb, 2014; Cox and Cherney, 2014). However, in none of these studies the reason for the variation observed between locations were identified. Two studies in canola and peanut, respectively, found that local differences in the effect of seed treatment correlated well with differences in rainfall (Rife and Buntin, 2007) and with differences in water stress and crop rotation (Turner and Backman, 1991). Only the last report analysing seed treatment and crop rotation provides direct evidence to support a hypothesis of differences in the pressure from soil-borne pathogens being an important factor determining the effect of seed treatment. However, all six studies clearly confirm that local variations in the effect of seed treatment have been found in several crops.

Root associated mycoflora. Three species of fungi were found to be more abundantly occurring in roots from fields near Diapangou (low crop performance, large effect of seed treatment) compared to roots from Kindi: Fusarium equiseti, Macrophomina phaseolina and Curvularia lunata (Table 7). Fusarium equiseti has previously been identified as the most abundant species of fungus in roots of mature sorghum in the US (Reed and Partridge, 1983), and an isolate from sorghum in Burkina Faso has been shown to be pathogenic in seedlings of sorghum, when inoculated to seeds (Zida et al., 2008b). The two other species that were overrepresented in roots from Diapangou, M. phaseolina and C. lunata are, both known as important seed- and soil-borne pathogens of sorghum causing charcoal rot and grain mold/reduced germination, respectively (Frederiksen, 2000, Prom et al., 2004). As a mean, these three species were found to constitute $58 \%$ of fungal DNA in sorghum roots from Diapangou, compared to only $20 \%$ in roots from Kindi (calculated from Table 7). The most dominating groups of fungi associated with roots from Kindi, were unknown species of Sordariales, in particular one related to a species previously identified in tropical grasses (Herrera et al., 2013) and fungal species closely related to Penicillium. None of these two taxa are known as pathogens in sorghum. Overall, the DNA profiling of the root associated mycoflora supported the hypothesis that fungal pathogens are more abundant in the soil of Diapangou than in the soil of Kindi. Thus, if any of the seed treatments can cause a delay of or suppress soil-borne infection, this could explain some of the differences in the response to treatments found between villages in this study.

Perspectives. From our results, the effect of seed treatment with either Calthio C or E. alba extracts have a positive effect on yield, but not in all fields. However, the finding that "Village" was the factor most strongly influencing the yield response is encouraging in terms of knowledge dissemination because farmers beneficiary of the technology are then most likely co-located to some extent.

The two villages showing the most promising effects, Diapangou and Ipendo (Fig. 1) are both located on a geographical line running East-West in Burkina Faso, approximately $30 \mathrm{Km}$ south of the capital Ouagadougou; whereas most of the other villages, of which several showed over all negative results (Bani, You, Kindi, Zorgho), are located north of this line. Since the effect of $E$. alba extract in both villages (Diapangou and Ipendo) appeared to be positive and robust (20$40 \%$ yield increase, 17 and 24 field tests respectively, Fig.1), it could make sense to focus solely on the plant extract since the pesticide, Calthio C, is toxic to humans (Cereser et al., 2001; Pino et al., 2015) and protective measures for farmers using this agent in Burkina Faso are insufficient (Toe et al., 2013). In addition, the plant, E. alba, can easily be found near the two villages Diapangou and Ipendo(Zida et al., unpublished results). Field testing along the line between the villages, Diapangou and Ipendo, and South of this line, most likely could identify new areas/villages where a positive response to seed treatment of sorghum with $E$. alba extract would be observed. According to our recent findings (Zida et al., 2015) this field testing could be conducted using a shortened soaking time of seeds ( 6 hours) and a reduced concentration of E. alba extract (down to 2.5\%) and in this way introduce a more feasible procedure to farmers compared to the protocols used in the present study. 


\section{ACKNOWLEDGMENT}

The technical assistance of Lene Klem is gratefully acknowledged. We thank the Danish Ministry of Foreign Affairs for the grant: Performance-contract for 2011-2012 for Danish Seed Health Centre, and for the grant 09-065 LIFE for the project "Exploiting African Seed Treatment Technology". We further thank the European Union for the Grant No. DCI-FOOD/2012/304690 under the Europe AID programme.

\section{REFERENCES}

Aveskamp, M.M., de Gruyter, J., Woudenberg, J.H.C., Verkley, G.J.M. and Crous, P.W. 2010. Highlights of the Didymellaceae: A polyphasic approach to characterise Phoma and related pleosporalean genera. Studies in Mycology 65:1-60.

Barron, M.G. and Woodburn, K.B. 1995. Ecotoxicology of chlorpyrifos. Rev Environ Contam Toxicol 144:1-93.

Bensch, K., Groenewald, J.Z., Dijksterhuis, J., Starink-Willemse, M., Andersen, B., Summerell, B.A., Shin, H.D., Dugan, F.M., Schroers, H. J., Braun, U. and Crous, P.W. 2010. Species and ecological diversity within the Cladosporium cladosporioides complex (Davidiellaceae, Capnodiales). Studies in Mycology 67:1-94.

Bradley, C.A. 2008. Effect of fungicide seed treatments on stand establishment, seedling disease and yield of soybean in North Dakota. Plant Disease 92:120-125.

Cereser, C., Boget, S., Parvaz, P. and Revol, A. 2001. An evaluation of thiram toxicity on cultured human skin fibroblasts. Toxicology 162:89-101.

Cox, W.J. and Cherney, J.H. 2014. Soybean seed treatments interact with locations for populations, yield, and partial returns. Agronomy Journal 106:2157.

Durling, M. B., Clemmensen, K. E., Stenlid, J. and Lindahl, B. 2011. SCATA - An efficient bioinformatic pipeline for species identification and quantification after highthroughput sequencing of tagged amplicons. SCATA Program accessed online 1. Dec. 2015: http://scata.mykopat.slu.se/
Elskens, M.T. and Penninckx, M.J. 1995. In vitro inactivation of yeast glutathione reductase by tetramethylthiuram disulphide. The FEBS Journal 231:667-672.

FAO. 2011. United Nations Food and Agriculture Organization (FAO) homepage http:// www.fao.org displaying a general description of the sorghum crop: Sorghum bicolor (L.) Moench. Accessed 1 August 2011.

Frederiksen, R.A. 2000. Diseases and disease management in sorghum. In: Sorghum: Origin, history, technology and production. Smith C.W. and Frederiksen, R.A. Published by John Wiley \& Sons, Inc. (New York). pp. 497-533.

Girish, A.G., Deepti, S., Rao, V.P. and Thakur, R.P. 2004. Detection of seedborne grain mould fungi in sorghum and their control with fungicidal seed treatment. International Sorghum and Millets Newsletter 45: 31-33.

Hammer, Ø., Harper, D.A.T. and Ryan, P.D. 2001. PAST: Paleontological statistics software package for education and data analysis. Palaeontologia Electronica 4(1): 9.

Hasan, H.A. 2001. Phytotoxicity of pathogenic fungi and their mycotoxins to cereal seedling viability. Mycopathologia 148: 149-55.

Herrera, J., Poudel, R. and Bokati, D. 2013. Assessment of root-associated fungal communities colonising two species of tropical grasses reveals incongruence to fungal communities of North American native grasses. Fungal Ecology 6:65-69.

Jahan, R., Al-Nahain, A., Majumder, S. and Rahmatullah, M. 2014. Ethno-pharmacological significance of Eclipta alba (L.) Hassk. (Asteraceae). International Scholarly Research Notices, Vol 2014, article ID: 385969 , 22 pages, Hindawi Publ. Corp.

Louarn, S., Nawrocki, A., Thorup-Kristensen, K., Lund, O.S., Jensen, O.N., Collinge, D.B. and Jensen, B. 2013. Proteomic changes and endophytic micromycota during storage of organically and conventionally grown carrots. Postharvest Biology and Technology 76:2633.

Manamgoda, D.S., Cai, L., McKenzie, E.H.C., Crous, P.W., Madrid, H., Chukeatirote, E., Shivas, R.G., Tan, Y. P. and Hyde, K.D. 2012. A phylogenetic and taxonomic re-evaluation of 
the Bipolaris-Cochliobolus-Curvularia complex. Fungal Diversity 56:131-144.

O’Donnell, K., Sutton, D.A., Rinaldi, M.G., Gueidan, C., Crous, P.W. and Geiser, D.M. 2009. Novel multilocus sequence typing scheme reveals high genetic diversity of human pathogenic members of the Fusarium incarnatum- $F$. equiseti and $F$. chlamydosporum species complexes within the United States. Journal of Clinical Microbiology 47:3851-3861.

Paul, P.A., Madden, L.V., Bradley, C.A., Robertson, A.E., Munkvold, G.P., Shaner, G., Wise, K.A., Malvick, D.K., Allen, T.W., Grybauskas, A., Vincelli, P. and Esker, P. 2011. Meta-analysis of yield response of hybrid field corn to foliar fungicides in the U.S. corn belt. Phytopathology 101:1122-1132.

Pazoutová, S. 2009. Genetic variation of Phoma sorghina isolates from Southern Africa and Texas. Folia Microbiology 54:217-229.

Pino, J.D., Moyana, P., Anadon, M.J., Garcia, J.M., Diaz, M.J., Garcia, J. and Frejo, M.T. 2015. Acute and long term exposure to chlorpyrifos induces cell death of basal forebrain cholinergic neurons through AchE variants alteration. Toxicology 336:1-9.

Prom, L.K. 2004. The effects of Fusarium thapsinum, Curvularia lunata, and their combination on sorghum germination and seed mycoflora. Journal of New Seeds 6:3949.

R Core Team. 2015. R: A language and environment for statistical computing. Published by R Foundation for Statistical Computing, Vienna, Austria at URL https:// www.R-project.org.

Reed, J.E. and Partridge, J.E. 1983. Fungal colonisation of stalks and roots of grain sorghum during the growth season. Plant Disease 67: 417-420.

Rife, C. and Buntin, D. 2007. Effect of an insecticide and fungicide seed treatment on canola production and yield under varying levels of precipitation. 12th Rapeseed Congress Proceedings 4:271-273.

Samson, R.A. Yilmaz, N., Houbraken, J., Spierenburg, H., Seifert, K.A., Peterson, S.W. Varga, J. and Frisvad, J.C. 2011. Phylogeny and nomenclature of the genus Talaromyces and taxa accommodated in Penicillium subgenus Biverticillium. Studies in Mycology 70:159-183.

Saraswathy, N. and Kumaran, P.M. 2012. Evaluation of aqueous extract of Eclipta alba leaves for preservative potential against Fusarium species. American Journal of PharmTech Research 5:647-649.

Schulz, T.J. and Thelen, K.D. 2008. Soybean seed inoculant and fungicidal seed treatment effects on soybean. Crop Science 48:19751983.

Slippers, B., Boissin, E., Phillips A.J.L., Groenewald, J.Z., Lombard, L. Wingfield, M.J., Postma, A., Burgess, T. and Crous, P.W. 2013. Phylogenetic lineages in the Botryosphaeriales: A systematic and evolutionary framework. Studies in Mycology 76:31-49.

Soltani, E. and Soltani, A. 2015. Meta-analysis of seed-priming effects on seed germination, seedling emergence and crop yield: Iranian studies. International Journal of Plant Production 9:413-431.

Sudozai, M.I., Tunio, S., Chachar, Q. and Rajpar, I. 2013. Seedling establishment and yield of maize under different seed priming periods and available soil moisture. Sarhad Journal of A griculture 29:515-528.

Toe, A.M., Ouedrago, M., Ouedrago, R., Ilboudo, S. and Guissou, P.I. 2013. Pilot study on agricultural pesticide poisoning in Burkina Faso. Interdiciplinary Toxicology 6:185-191.

Turner, J.C. and Backman, P.A.1991. Factors relating to peanut yield increases after seed treatment with Bacillus subtilis. Plant Disease 75:347-353.

Wohleb, C.H. 2014. Evaluation of fungicide seed treatments for sweet corn. Journal of NACAA 7(2) ISSN 2158-9429. Ed.; Stephen C. Brown, on-line publication URL: http://www.nacaa. com/journal/index.php?jid=426

Zida, E.P., Sérémé, P., Leth, V. and Sankara, P. 2008a. Effect of aqueous extracts of Acacia gourmaensis A, Chev and Eclipta alba (L.) Hassk. on seed health, seedling vigour and grain yield of sorghum and pearl millet. Asian Journal of Plant Pathology 2:40-47.

Zida, P.E., Sérémé, P., Leth, V., Sankara, P., Somda, I. and Néya, A. 2008b. Importance of seed- 
borne fungi of sorghum and pearl millet in Burkina Faso and their control using plant extracts. Pakistan Journal of Biological Sciences 11:321-331.

Zida, P.E., Lund, O.S. and Néya, J.B. 2012. Seed treatment with a binary pesticide and aqueous extract of Eclipta alba (L.) Hassk. for improving sorghum yield in Burkina Faso. Journal of Tropical Agriculture 50:1-7.
Zida, P.E., Néya, J.B., Soalla, W.R., Prakash, H.S., Niranjana, S.R., Udayashankar, A.C,. Nandini, M., Rajini, S.B., Barrocas, E.N., Andresen, M., Sérémé, P. and Lund, O.S. 2015. Increased feasibility of treating sorghum seeds with Eclipta alba extract by lowering concentration of plant extract and soaking time of seeds. International Journal of Tropical Agriculture 33:2391-2400. 